\title{
Stigma and HIV risk behaviors of transgender women in Nepal: implications for HIV prevention
}

\author{
Erin Wilson ${ }^{1 *}$, Sunil Babu Pant ${ }^{2}$ \\ From $16^{\text {th }}$ International Symposium on HIV and Emerging Infectious Diseases \\ Marseille, France. 24-26 March 2010
}

\section{Background}

The growing HIV epidemic among Metis (i.e. transgender women) in Nepal has important implications for this at-risk population and the country overall. In order to develop interventions targeting this population, researchers must better understand the unique cultural context within which risk behavior occurs. This study was conducted to explore the social context of HIV risk behavior among Metis in Kathmandu, Nepal.

\section{Methods}

Qualitative data were collected using in-depth interviews with fourteen Metis. These data were taken from a larger study with a purposeful convenience sample of men who have sex with men in Kathmandu, Nepal. Seven Metis reported currently being sex workers, while seven reported not currently engaging in sex work but having a history of providing sex for money.

\section{Results}

Utilizing a phenomenological approach, we found that stigma towards Metis resulting in discrimination by family members, law enforcement, and employers had an important effect on HIV risk for Metis. Specific HIVrelated risks identified were rape and abuse by law enforcement officers leading to inconsistent condom use due to fear of carrying condoms in public. Low access and ability to carry condoms paired with high reported numbers of sexual partners revealed an environment ripe for the spread of HIV among Metis and their partners.

\section{Discussion}

These data suggest the imminent need for interventions to reduce law enforcement violence towards Metis in

\footnotetext{
* Correspondence: erin.wilson@ucsf.edu

${ }^{1}$ Center for AIDS Prevention Studies, San Francisco, USA
}

order to decrease the risk for HIV among Metis who are raped and to increase access to and the ability to safely carry condoms. Sensitivity trainings and strict enforcement of existing legal protections for Metis should be considered. Interventions targeting risk reduction among Meti sex workers are also needed, in addition to programs that focus on providing alternative forms of employment for Metis that face discrimination in the workplace and from families. Further research to inform anti-stigma campaigns and foster a better understanding by family members of Meti identity may also have an important impact on reducing discrimination, subsequently having an impact on HIV risk behavior within this at-risk population.

\section{Author details}

${ }^{1}$ Center for AIDS Prevention Studies, San Francisco, USA. ${ }^{2}$ Blue Diamond Society, Kathmandu, Nepal.

Published: 11 May 2010

doi:10.1186/1742-4690-7-S1-P122

Cite this article as: Wilson and Pant: Stigma and HIV risk behaviors of transgender women in Nepal: implications for HIV prevention. Retrovirology 2010 7(Suppl 1):P122.

Submit your next manuscript to BioMed Central and take full advantage of:

- Convenient online submission

- Thorough peer review

- No space constraints or color figure charges

- Immediate publication on acceptance

- Inclusion in PubMed, CAS, Scopus and Google Scholar

- Research which is freely available for redistribution

Submit your manuscript at www.biomedcentral.com/submit
C Biomed Central 